\title{
Characterization of the Teleneurology Patients at the Hospital Las Higueras de Talcahuano - Chile
}

\begin{abstract}
Freddy Constanzo ${ }^{1,2 *}$, Paula Aracena-Sherck ${ }^{3}$, Lorena Peña ${ }^{1,2}$, Mery Marrugo ${ }^{1,2}$, Jonathan Gonzalez ${ }^{1,2}$, Gerardo Vergara ${ }^{4}$ and Cristóbal Alvarado ${ }^{3,5}$

${ }^{1}$ Neurology Unit, Hospital Las Higueras, Talcahuano, Chile, ${ }^{2}$ Medical Program in Adult Neurology, School of Medicine, Universidad Católica de la Santísima Concepción, Concepción, Chile, ${ }^{3}$ Department of Science, School of Medicine and Science, Universidad San Sebastián, Concepción, Chile, ${ }^{4}$ Unit of Teleprocesses, Hospital Las Higueras, Talcahuano, Chile, ${ }^{5}$ Department of Basic Sciences, School of Medicine, Universidad Católica de la Santísima Concepción, Concepción, Chile
\end{abstract}

Background: Chile has a shortage of medical experts, including neurologists. The remote neurology program at Las Higueras Hospital in Talcahuano (HHT) was implemented in 2015 to decrease the number of patients waiting for their first appointment.

OPEN ACCESS

Edited by:

Jack Tsao,

University of Tennessee Health

Science Center (UTHSC),

United States

Reviewed by:

Anna Hohler,

Boston University, United States

Roger Hesselbrock

JYG Innovations, Dayton,

United States

${ }^{*}$ Correspondence:

Freddy Constanzo

teleneurologiahht@gmail.com

Specialty section:

This article was submitted to

Neuroepidemiology,

a section of the journal

Frontiers in Neurology

Received: 17 August 2020

Accepted: 12 October 2020

Published: 19 November 2020

Citation:

Constanzo F, Aracena-Sherck P, Peña L, Marrugo M, Gonzalez J, Vergara $G$ and Alvarado C (2020) Characterization of the Teleneurology Patients at the Hospital Las Higueras

de Talcahuano-Chile.

Front. Neurol. 11:595577.

doi: 10.3389/fneur.2020.595577
Methods: This retrospective study analyzed a cohort of 2,904 ambulatory patients evaluated in the teleneurology program at the HHT between 2015 and 2019 who were referred from 16 primary and 3 tertiary healthcare centers.

Results: Out of the 2,904 patients included in the study, 1,020 patients (35\%) were male, and 1,884 (65\%) were female. In total, 1,346 (46.0\%) patients were under 60 years old (408 male and 938 female), and 1,558 (54\%) were over 60 years old (612 male and 946 female). The patients were referred to a neurologist in the teleneurology program from different primary healthcare centers (93.5\%) and tertiary healthcare centers (6.5\%). The most common diseases diagnosed through teleneurology were, in decreasing order, headache (29.4\%), Alzheimer's disease and other dementias (15.9\%), and epilepsy (11.4\%). From July 2018, we analyzed the patients' destination after the first teleneurology consultation. In the cohort of 634 patients who had their first consultation via the teleneurology program, 547 (86.3\%) were instructed to continue follow-up via telemedicine.

Conclusions: Data from this study show, for the first time in Chile, the significant contribution of the teleneurology program at the HHT to the diagnosis of a broad range of diseases in a substantial number of patients referred from primary and tertiary healthcare centers.

Keywords: telemedicine, teleneurology, adult neurology, pathologies, waiting-list

\section{BACKGROUND}

Chile is a South American country with 19,458,310 inhabitants as of 2020 (1), with a lack of medical specialists. Most of the specialists work in the tertiary healthcare system, which is concentrated in large cities $(2,3)$. Currently, Chile has 605 licensed neurologist (4), but only 292 neurologists currently work in the public healthcare system $(4,5)$, which provides medical care to $\sim 80 \%$ of the 
total population (6). Hence, the number of patients waiting for their first appointment increases every year, and neurology ranks seventh among Chilean medical specialties; as of December 2019 , there were 57,837 patients waiting for a first appointment with a neurologist (7). The lack of timely access to medical services is a growing national problem, especially among people with disabilities such as those with neurological diseases $(7,8)$. The shortage of medical specialists has exacerbated the country's geographical difficulties in delivering tertiary healthcare; however, this situation provides an opportunity for telemedicine to improve patient access to professional medical services. Therefore, the implementation and the development of telemedicine in the Chilean public healthcare system is a good means of overcoming the shortage of experts and the transportation problems for ambulatory patients (9) and acute stroke patients (10).

The Talcahuano Health Service started the teleneurology program in March 2015 to help manage adult neurological patients waiting for their first consultation (9). The program runs in a synchronous mode, in which the ambulatory patient consults a general practitioner, who has been trained for this purpose in a local medical institution and connects the patient with a neurologist at the Hospital Las Higueras de Talcahuano (HHT) via an HDTV video conference system (11). The teleneurology program allows the remote care of patients at local primary and secondary medical institutions and has been shown to improve access to medical care from neurologists, with high levels of user satisfaction (11-13). Furthermore, the teleneurology program has also produced very good results with regard to reducing the waiting list for a first consultation, providing follow-up visits for patients with adequate control of their condition (9) and maintaining access to services during the coronavirus disease 2019 pandemic (14-16).

The burden of neurological disease is similar among different countries, with some differences depending mainly on the level of development, and it is measured annually (17-19). The primary neurological diseases are motor neuron diseases, multiple sclerosis, tetanus, other neurological disorders, Parkinson's disease, encephalitis, tension-type headache, brain and other central nervous system (CNS) cancers, traumatic brain injury, spinal cord injury, epilepsy, meningitis, Alzheimer's disease and other dementias, migraine, and stroke. Therefore, it is necessary to reorganize the different levels of the healthcare system to face these challenges. The systematic use of teleneurology has been shown to be effective for many neurological disorders $(9,20,21)$. Recent studies have provided a detailed description of the types of pathologies that can be efficiently treated through telemedicine (20-22); however, in Chile, there are no published reports that describe the most common neurological pathologies that could be treated by teleneurology in outpatient clinics. In this study, we performed a retrospective analysis of 2,904 patients who were examined, diagnosed, and treated between 2015 and 2019 in the teleneurology program at HHT. In addition, we classified the patients by sex, age, place of origin, and

Abbreviations: NU, Neurology Unit; HHT, Hospital las Higueras of Talcahuano (HHT); SST, Health Service of Talcahuano of the Ministry of Health. diagnosis, with the aim of demonstrating that teleneurology manages to address the majority of diseases contributing to the ambulatory neurological disease burden in Chile. This manuscript, for the first time in Chile, details the most common pathologies in ambulatory patients in Chile that can be managed by teleneurology.

\section{METHODS}

\section{Description of the Study Population}

This retrospective cohort study analyzed the data of patients who accessed the teleneurology program between June 2015 and October 2019. All the patients included in this study had their first appointment with the neurologist by telepresence (synchronous clinic videoconference); the details are described in Constanzo et al. (11). The patients included in this study were referred from the following primary health departments that depend on the HHT: (i) community family health centers (CECOSF for the Spanish acronym): CECOSF 8 mayo, CECOSF Esmeralda, CECOSF Leocán Portus, CECOSF Libertad Gaete, and CECOSF Los Lobos-La Gloria; (ii) family health centers (CESFAM for the Spanish acronym): CESAFM Paulina Avendaño Pereda, CESFAM Bellavista, CESFAM Dr. Alberto Reyes, CESFAM Hualpencillo, CESFAM La Floresta, CESFAM Lirquén, CESFAM Los Cerros, CESFAM Penco, CESFAM San Vicente, CESFAM Talcahuano Sur, CESFAM Alcalde Leocán Portus, and the Community Dementia Centre (CDC) Kelluwün; and (iii) tertiary healthcare centers: HHT, Tomé Hospital, and Penco-Lirquén Hospital.

\section{Teleneurology System}

The teleneurology program implemented at the HHT combines the simultaneous live care by a general practitioner in situ and the remote primary care offered by a neurology specialist in specifically designed HHT facilities. For each video session in the teleprocess unit (synchronous), a referral and a reference web platform are used, which is integrated in the hospital electronic clinical record with an HL7 standard and has a Secure Sockets Layer security server for encryption. The inclusion and the exclusion criteria for the patients in this study were previously described in Constanzo et al. (11) (Supplementary Table 1). During this study, the HHT Neurology Unit consisted of 11 neurologists and two general practitioners. The neurologist group dedicated, as a group, $74 \mathrm{~h}$ per week to consultation in situ at HHT and $17 \mathrm{~h}$ per week to the teleneurology program. The general practitioners dedicated, as a group, $21 \mathrm{~h}$ per week for (i) coordination of care and follow-up of patients waiting for an appointment, (ii) extension of chronic patient prescriptions, and (iii) follow-up of patients with a prolonged medical license or in the process of requesting a disability pension (9). This allows the team of neurologists to focus exclusively on the resolution of the patients' neurological problems. Finally, all participant nneurologists receive training in teleneurology by the Teleneurology Unit at the HHT in association with the Universidad Católica de la Santísima Concepción, Chile. 


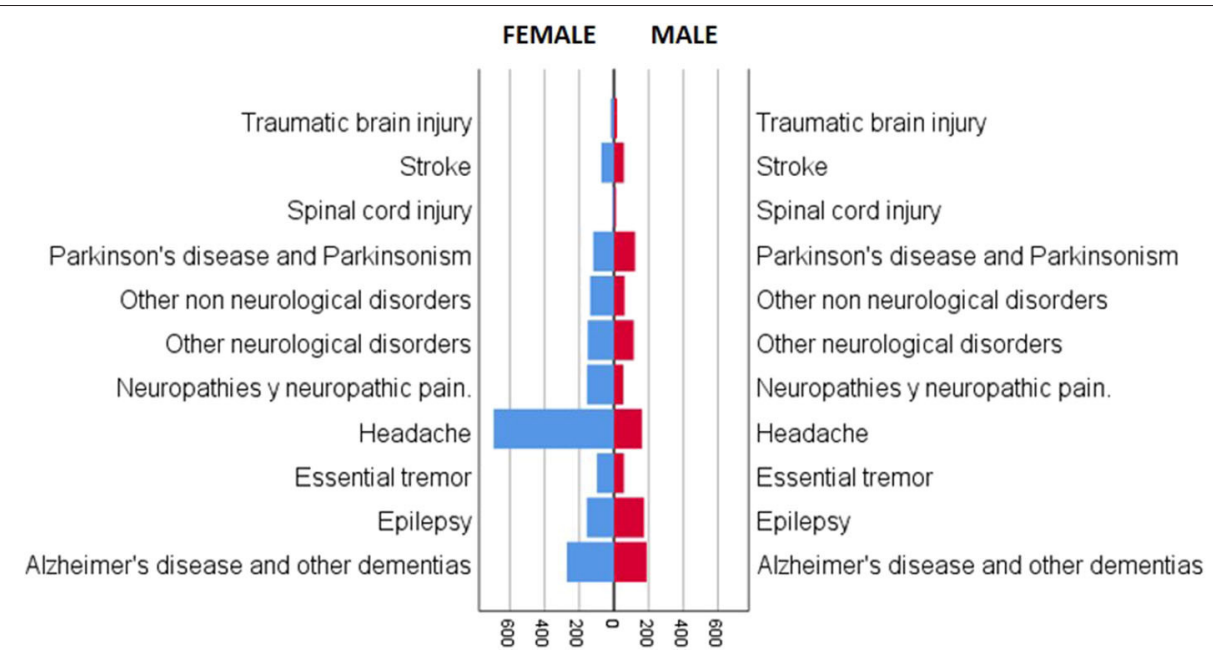

FIGURE 1 | Patients categorized by gender (female and male) in the teleneurology program at the Hospital las Higueras of Talcahuano.

\section{Neurological Diseases Attended in the Teleneurology Program}

The teleneurology patients were categorized as follows: (i) headache: chronic migraine, migraine, tension-type headache, chronic tension-type headache, and other headaches; (ii) Alzheimer's disease and other dementias: Alzheimer's disease, dementia syndrome (first evaluation), mild cognitive impairment, vascular and Alzheimer's dementia, vascular dementia, Lewy body dementia, traumatic brain injury dementia, and other dementias; (iii) epilepsy; (iv) other neurological disorders: brain and other CNS cancer, vertigo, motor mononeuropathy (ocular and facial), intellectual disability, hemifacial spasm, tics and dystonia, ataxias, sleep disorders, motor neuron disease, dystrophies and myotonias, myasthenia gravis, and others; (v) Parkinson's disease and parkinsonism: Parkinson's disease, parkinsonian syndrome (first evaluation), atypical parkinsonian disorders; (vi) neuropathies and neuropathic pain: polyneuropathy, radiculopathy, trigeminal neuralgia, postherpetic neuralgia, and others; (vii) other nonneurological disorders: syncope, other psychiatric disorders; depression; fibromyalgia, and others; (viii) essential tremor; (ix) stroke: ischemic, hemorrhagic, transient ischemic attack (TIA), others; (x) traumatic brain injury; and (xi) spinal cord injury.

\section{Statistical Analysis}

The descriptive analysis of patient data is reported here as the frequencies and the percentages for continuous and categorical variables. All analyses were performed with SPSS, version 25 .

\section{RESULTS}

\section{Patient Cohort Description}

This retrospective cohort study included 2,904 patients who were evaluated in the teleneurology program between June 2015 and
October 2019. In summary, 1,020 patients (35\%) were male, and 1,884 (65\%) were female (Figure 1, Table 1); 1,346 (46.0\%) patients were under 60 years old ( 408 male and 938 female), and $1,558(54 \%)$ were over 60 years old (612 male and 946 female) (Table 1). During the study period, we performed a total of 5,874 telepresence appointments; 2,904 (49\%) were first appointments, and 2,970 (51\%) were follow-up visits.

Interestingly, after July 2018, we were able to determine the medical referral destination of the patients after the first consultation. From a cohort of 634 first consultation patients, $547(86.3 \%)$ patients were instructed to continue follow-up via telemedicine, $50(7.9 \%)$ patients were referred to primary healthcare, and $37(5.8 \%)$ patients, given their complexity, were referred to the tertiary level of healthcare as follows: two $(0.3 \%)$ patients to the emergency department, five $(0.8 \%)$ patients for hospitalization, eight (1.3\%) patients to another specialty, and $22(3.5 \%)$ patients to face-to-face consultation with a neurologist (Figure 2).

\section{Health Centers Associated With the Teleneurology Program}

The patients were referred to a neurologist by telepresence from different primary healthcare centers (93.5\%) as follows (Table 1): community family health centers: CDC Kelluwün (2.2\%), CECOSF 8 mayo (0.4\%), CECOSF Esmeralda (1.0\%), CECOSF Leocán Portus (0.5\%), CECOSF Libertad Gaete (0.0\%), CECOSF Los Lobos-La Gloria (0.1\%); family health centers: CESFAM Paulina Avendaño Pereda (15.3\%), CESFAM Bellavista (1.8\%), CESFAM Dr. Alberto Reyes (5.4\%), CESFAM Hualpencillo (10.9\%), CESFAM La Floresta (8.7\%), CESFAM Lirquén (1.5\%), CESFAM Los Cerros (7.3\%), CESFAM Penco (6.6\%), CESFAM San Vicente (11.0\%), CESFAM Talcahuano Sur $(9.0 \%)$, and CESFAM Alcalde Leocán Portus (11.8\%); and tertiary healthcare centers (6.5\%): Tomé Hospital (4.3\%), HHT (0.3\%), and PencoLirquén Hospital (1.9\%) (Table 1). 
TABLE 1 | Patients categorized by age (under 60 and over 60), and place of origin in the teleneurology program at the Hospital las Higueras of Talcahuano.

\begin{tabular}{|c|c|c|c|c|c|c|}
\hline & Female & $\%$ & Male & $\%$ & $\begin{array}{c}\text { Total } \\
(n=2,904)\end{array}$ & $\%$ \\
\hline \multicolumn{7}{|l|}{ Age } \\
\hline Total & 1,884 & $65 \%$ & 1,020 & $35 \%$ & 2,904 & $100.0 \%$ \\
\hline Under 60 years & 938 & $32.3 \%$ & 408 & $14.0 \%$ & 1,346 & $46.3 \%$ \\
\hline Over 60 years & 946 & $32.6 \%$ & 612 & $21.1 \%$ & 1,558 & $53.7 \%$ \\
\hline \multicolumn{7}{|l|}{ Place of origin } \\
\hline CDC Kelluwün & 35 & $1.2 \%$ & 29 & $1.0 \%$ & 64 & $2.2 \%$ \\
\hline CECOSF 8 mayo & 9 & $0.5 \%$ & 2 & $0.1 \%$ & 11 & $0.4 \%$ \\
\hline CECOSF Esmeralda & 18 & $1.0 \%$ & 10 & $0.3 \%$ & 28 & $1.0 \%$ \\
\hline $\begin{array}{l}\text { CECOSF Libertad } \\
\text { Gaete }\end{array}$ & 1 & $0.1 \%$ & 0 & $0.0 \%$ & 1 & $0.0 \%$ \\
\hline $\begin{array}{l}\text { CECOSF Los } \\
\text { Lobos-La Gloria }\end{array}$ & 2 & $0.1 \%$ & 0 & $0.0 \%$ & 2 & $0.1 \%$ \\
\hline $\begin{array}{l}\text { CESFAM Paulina } \\
\text { Avendaño Pereda }\end{array}$ & 283 & $15.0 \%$ & 162 & $5.6 \%$ & 445 & $15.3 \%$ \\
\hline CESFAM Bellavista & 36 & $1.9 \%$ & 15 & $0.5 \%$ & 51 & $1.8 \%$ \\
\hline $\begin{array}{l}\text { CESFAM Dr. Alberto } \\
\text { Reyes }\end{array}$ & 108 & $5.7 \%$ & 50 & $1.7 \%$ & 158 & $5.4 \%$ \\
\hline CESFAM Hualpencillo & 201 & $10.7 \%$ & 116 & $4.0 \%$ & 317 & $10.9 \%$ \\
\hline CESFAM La Floresta & 178 & $9.4 \%$ & 74 & $2.5 \%$ & 252 & $8.7 \%$ \\
\hline CESFAM Lirquén & 23 & $1.2 \%$ & 22 & $0.8 \%$ & 45 & $1.5 \%$ \\
\hline CESFAM Los Cerros & 139 & $7.4 \%$ & 74 & $2.5 \%$ & 213 & $7.3 \%$ \\
\hline CESFAM Penco & 133 & $7.1 \%$ & 58 & $2.0 \%$ & 191 & $6.6 \%$ \\
\hline CESFAM San Vicente & 216 & $11.5 \%$ & 102 & $3.5 \%$ & 318 & $11.0 \%$ \\
\hline $\begin{array}{l}\text { CESFAM Talcahuano } \\
\text { Sur }\end{array}$ & 169 & $9.0 \%$ & 93 & $3.2 \%$ & 262 & $9.0 \%$ \\
\hline $\begin{array}{l}\text { CESFAM Alcalde } \\
\text { Leocán Portus }\end{array}$ & 234 & $12.4 \%$ & 123 & $4.2 \%$ & 357 & $12.3 \%$ \\
\hline Hospital de Tomé & 69 & $3.7 \%$ & 56 & $1.9 \%$ & 125 & $4.3 \%$ \\
\hline Hospital Las Higueras & 6 & $0.3 \%$ & 4 & $0.1 \%$ & 10 & $0.3 \%$ \\
\hline Hospital Penco Lirquén & 24 & $1.3 \%$ & 30 & $1.0 \%$ & 54 & $1.9 \%$ \\
\hline Total & 1,884 & $100.0 \%$ & 1,020 & $35.1 \%$ & 2,904 & $100 \%$ \\
\hline
\end{tabular}

\section{Characterization of Neurological Diseases Attended in the Teleneurology Program}

The patients were stratified by pathology, from the most common to the least as follows: (i) headache -855 (29\%): chronic migraine $-309(10.6 \%)$, migraine $-253(8.7 \%)$, tension-type headache -146 (5\%), chronic tension-type headache -131 (4.5\%), and other headaches -16 (0.6\%); (ii) Alzheimer's disease and other dementias -461 (15.9\%): Alzheimer's disease -227 (7.8\%), dementia syndrome (first evaluation) -79 (2.7\%), mild cognitive impairment -72 (2.5\%), vascular and Alzheimer's dementia - 30 (1\%), other dementias $-29(1 \%)$, vascular dementia - $14(0.5 \%)$, Lewy body dementia-seven $(0.2 \%)$, traumatic brain injury dementia-three (0.1\%); (iii) epilepsy -331 (11.4\%); (iv) other neurological disorders -265 (9.1\%): others -62 (2.1\%), brain and other CNS cancer -47 (1.6\%), vertigo -40 (1.4\%), motor mononeuropathy (ocular and facial) $-25(0.9 \%)$, intellectual disability $-23(0.8 \%)$, hemifacial spasm, tics, and dystonia $-18(0.6 \%)$, ataxias $-12(0.4 \%)$, sleep disorders $-12(0.4 \%)$,

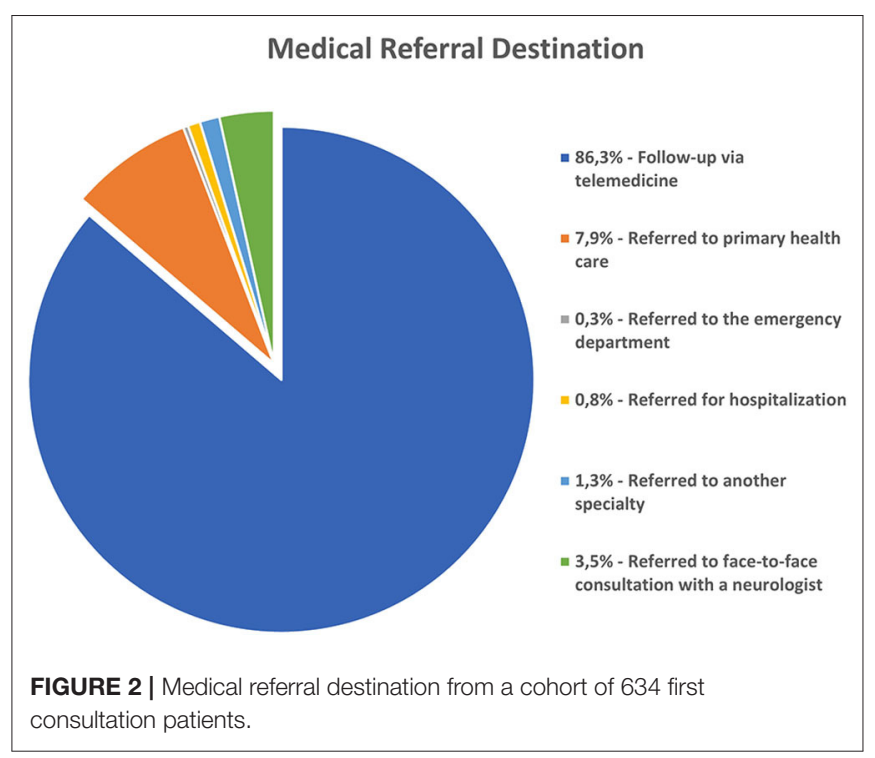

motor neuron disease $-10(0.3 \%)$, dystrophies and myotoniaseight $(0.3 \%)$, myasthenia gravis-eight (0.3\%); (v) Parkinson's disease and parkinsonism -242 (8.3\%): Parkinson's disease -177 (6.1\%), parkinsonian syndrome (first evaluation) -55 (1.9\%), atypical parkinsonian disorders -10 (0.3\%); (vi) neuropathies and neuropathic pain -210 (7.2\%): polyneuropathy -77 (2.7\%), radiculopathy $-42(1.4 \%)$, others $-25 \quad(0.9 \%)$, trigeminal neuralgia $-23(0.8 \%)$, postherpetic neuralgia -17 (0.6\%); (vii) other non-neurological disorders -199 (6.9\%): others -93 (3.2\%), syncope $-39(1.3 \%)$, other psychiatric disorders -34 (1.2\%), depression $-26(0.9 \%)$, fibromyalgia-seven (0.2\%); (viii) essential tremor -156 (5.4\%); (ix) stroke -130 (4.5\%): ischemic -93 (3.2\%), hemorrhagic $-23(0.8 \%)$, TIA $-13(0.4 \%)$, othersone ( $0 \%)$; $(\mathrm{x})$ traumatic brain injury $-36(1.2 \%)$; and (xi) spinal cord injury $-19(0.7 \%)$ (Table 2$)$.

\section{Characterization of Neurological Diseases by Age Attended in the Teleneurology Program}

The patients were stratified by age and pathology, from the most common to the least as follows (Figure 3): under 60 years old: (i) headache -625 (46\%), (ii) epilepsy -248 (18\%), (iii) other neurological disorders -133 (10\%), (iv) other non-neurological disorders $-110(8.2 \%)$, (v) neuropathies and neuropathic pain -87 (6.5\%), (vi) stroke -41 (3.0\%), (vii) essential tremor -32 (2.4\%), (viii) Alzheimer's disease and other dementias -26 (1.9\%), (ix) Parkinson's disease and parkinsonism -17 (1.3\%), (x) traumatic brain injury $-17(1.3 \%)$, and (xi) spinal cord injury $-10(0.7 \%)$ (Table 3); and over 60 years old: (i) Alzheimer's disease and other dementias -435 (28\%), (ii) headache -230 (15\%), (iii) Parkinson's disease and parkinsonism -225 (14\%), (iv) other neurological disorders -132 (8.5\%), (v) essential tremor -124 (8.0\%), (vi) neuropathies and neuropathic pain -123 (7.9\%), (vii) other non-neurological disorders -89 (5.7\%), (viii) stroke -89 (5.7\%), (ix) epilepsy -83 (5.3\%), (x) traumatic 
TABLE 2 | Patients categorized by neurological pathology in the teleneurology program at the Hospital las Higueras of Talcahuano.

\begin{tabular}{|c|c|c|c|c|c|c|}
\hline & Female & $\%$ & Male & $\%$ & Total & $\%$ \\
\hline Headache & 694 & $23.9 \%$ & 161 & $5.5 \%$ & 855 & $29.4 \%$ \\
\hline Chronic migraine & 266 & $9.2 \%$ & 43 & $1.5 \%$ & 309 & $10.6 \%$ \\
\hline Migraine & 216 & $7.4 \%$ & 37 & $1.3 \%$ & 253 & $8.7 \%$ \\
\hline Tension-type headache & 101 & $3.5 \%$ & 45 & $1.5 \%$ & 146 & $5.0 \%$ \\
\hline $\begin{array}{l}\text { Chronic tension-type } \\
\text { headache }\end{array}$ & 100 & $3.4 \%$ & 31 & $1.1 \%$ & 131 & $4.5 \%$ \\
\hline Other headaches & 11 & $0.4 \%$ & 5 & $0.2 \%$ & 16 & $0.6 \%$ \\
\hline $\begin{array}{l}\text { Alzheimer's disease } \\
\text { and other dementias }\end{array}$ & 272 & $9.4 \%$ & 189 & $6.5 \%$ & 461 & $15.9 \%$ \\
\hline Alzheimer's disease & 154 & $5.3 \%$ & 73 & $2.5 \%$ & 227 & $7.8 \%$ \\
\hline $\begin{array}{l}\text { Dementia syndrome } \\
\text { (first evaluation) }\end{array}$ & 32 & $1.1 \%$ & 47 & $1.6 \%$ & 79 & $2.7 \%$ \\
\hline $\begin{array}{l}\text { Mild cognitive } \\
\text { impairment }\end{array}$ & 40 & $1.4 \%$ & 32 & $1.1 \%$ & 72 & $2.5 \%$ \\
\hline $\begin{array}{l}\text { Vascular and } \\
\text { Alzheimer's dementia }\end{array}$ & 13 & $0.4 \%$ & 17 & $0.6 \%$ & 30 & $1.0 \%$ \\
\hline Other dementias & 17 & $0.6 \%$ & 12 & $0.4 \%$ & 29 & $1.0 \%$ \\
\hline Vascular dementia & 13 & $0.4 \%$ & 1 & $0.0 \%$ & 14 & $0.5 \%$ \\
\hline Lewy body dementia & 3 & $0.1 \%$ & 4 & $0.1 \%$ & 7 & $0.2 \%$ \\
\hline $\begin{array}{l}\text { Traumatic brain injury } \\
\text { dementia }\end{array}$ & 0 & $0.0 \%$ & 3 & $0.1 \%$ & 3 & $0.1 \%$ \\
\hline Epilepsy & 157 & $5.4 \%$ & 174 & $6.0 \%$ & 331 & $11.4 \%$ \\
\hline $\begin{array}{l}\text { Other neurological } \\
\text { disorders }\end{array}$ & 151 & $5.2 \%$ & 114 & $3.9 \%$ & 265 & $9.1 \%$ \\
\hline Others & 35 & $1.2 \%$ & 27 & $0.9 \%$ & 62 & $2.1 \%$ \\
\hline $\begin{array}{l}\text { Brain and other central } \\
\text { nervous system cancer }\end{array}$ & 29 & $1.0 \%$ & 18 & $0.6 \%$ & 47 & $1.6 \%$ \\
\hline Vertigo & 28 & $1.0 \%$ & 12 & $0.4 \%$ & 40 & $1.4 \%$ \\
\hline $\begin{array}{l}\text { Motor mononeuropathy } \\
\text { (ocular and facial) }\end{array}$ & 16 & $0.6 \%$ & 9 & $0.3 \%$ & 25 & $0.9 \%$ \\
\hline Intellectual disability & 6 & $0.2 \%$ & 17 & $0.6 \%$ & 23 & $0.8 \%$ \\
\hline $\begin{array}{l}\text { Hemifacial spasm, tics, } \\
\text { and dystonia }\end{array}$ & 12 & $0.4 \%$ & 6 & $0.2 \%$ & 18 & $0.6 \%$ \\
\hline Ataxias & 5 & $0.2 \%$ & 7 & $0.2 \%$ & 12 & $0.4 \%$ \\
\hline Sleep disorders & 5 & $0.2 \%$ & 7 & $0.2 \%$ & 12 & $0.4 \%$ \\
\hline Motor neuron disease & 2 & $0.1 \%$ & 8 & $0.3 \%$ & 10 & $0.3 \%$ \\
\hline $\begin{array}{l}\text { Dystrophies and } \\
\text { myotonias }\end{array}$ & 7 & $0.2 \%$ & 1 & $0.0 \%$ & 8 & $0.3 \%$ \\
\hline Myasthenia gravis & 6 & $0.2 \%$ & 2 & $0.1 \%$ & 8 & $0.3 \%$ \\
\hline $\begin{array}{l}\text { Parkinson's disease } \\
\text { and parkinsonism }\end{array}$ & 120 & $4.1 \%$ & 122 & $4.2 \%$ & 242 & $8.3 \%$ \\
\hline Parkinson's disease & 85 & $2.9 \%$ & 92 & $3.2 \%$ & 177 & $6.1 \%$ \\
\hline $\begin{array}{l}\text { Parkinsonian syndrome } \\
\text { (first evaluation) }\end{array}$ & 32 & $1.1 \%$ & 23 & $0.8 \%$ & 55 & $1.9 \%$ \\
\hline $\begin{array}{l}\text { Atypical parkinsonian } \\
\text { disorders }\end{array}$ & 3 & $0.1 \%$ & 7 & $0.2 \%$ & 10 & $0.3 \%$ \\
\hline $\begin{array}{l}\text { Neuropathies and } \\
\text { neuropathic pain }\end{array}$ & 156 & $5.4 \%$ & 54 & $1.9 \%$ & 210 & $7.2 \%$ \\
\hline Polyneuropathy & 50 & $1.7 \%$ & 27 & $0.9 \%$ & 77 & $2.7 \%$ \\
\hline Radiculopathy & 29 & $1.0 \%$ & 13 & $0.4 \%$ & 42 & $1.4 \%$ \\
\hline Others & 22 & $0.8 \%$ & 3 & $0.1 \%$ & 25 & $0.9 \%$ \\
\hline Trigeminal neuralgia & 22 & $0.8 \%$ & 1 & $0.0 \%$ & 23 & $0.8 \%$ \\
\hline Postherpetic neuralgia & 10 & $0.3 \%$ & 7 & $0.2 \%$ & 17 & $0.6 \%$ \\
\hline
\end{tabular}

(Continued)
TABLE 2 | Continued

\begin{tabular}{lcccccc}
\hline & Female & $\%$ & Male & $\%$ & Total & $\%$ \\
\hline $\begin{array}{l}\text { Other non-neurological } \\
\text { disorders }\end{array}$ & 138 & $4.8 \%$ & 61 & $2.1 \%$ & 199 & $6.9 \%$ \\
Others & 67 & $2.3 \%$ & 26 & $0.9 \%$ & 93 & $3.2 \%$ \\
Syncope & 24 & $0.8 \%$ & 15 & $0.5 \%$ & 39 & $1.3 \%$ \\
Other psychiatric & 20 & $0.7 \%$ & 14 & $0.5 \%$ & 34 & $1.2 \%$ \\
disorders & & & & & & \\
Depression & 20 & $0.7 \%$ & 6 & $0.2 \%$ & 26 & $0.9 \%$ \\
Fibromyalgia & 7 & $0.2 \%$ & 0 & $0.0 \%$ & 7 & $0.2 \%$ \\
Essential tremor & 98 & $3.4 \%$ & 58 & $2.0 \%$ & 156 & $5.4 \%$ \\
Stroke & 72 & $2.5 \%$ & 58 & $2.0 \%$ & 130 & $4.5 \%$ \\
Ischemic & 49 & $1.7 \%$ & 44 & $1.5 \%$ & 93 & $3.2 \%$ \\
Hemorrhagic & 16 & $0.6 \%$ & 7 & $0.2 \%$ & 23 & $0.8 \%$ \\
Transient ischemic & 7 & $0.2 \%$ & 6 & $0.2 \%$ & 13 & $0.4 \%$ \\
attack & & & & & & \\
Others & 0 & $0.0 \%$ & 1 & $0.0 \%$ & 1 & $0.0 \%$ \\
Traumatic brain injury & 18 & $0.6 \%$ & 18 & $0.6 \%$ & 36 & $1.2 \%$ \\
Spinal cord injury & 8 & $0.3 \%$ & 11 & $0.4 \%$ & 19 & $0.7 \%$ \\
\hline & & & & & & \\
\hline
\end{tabular}

brain injury $-19(1.2 \%)$, and (xi) spinal cord injury - nine $(0.6 \%)$ (Table 3).

\section{DISCUSSION}

Neurological disorders are recognized as a group of increasingly common diseases due to an increase in the life expectancy of the population and the current lifestyle (23). Neurological diseases impose a high disease burden on patients, their families, and society (17). In Chile, this problem is more acute than in developed countries due to the shortage of neurologists and the concentration of the existing neurologists in the country's large cities (3).

Telemedicine provides the opportunity to improve patient access to specialized medical care, especially for patients with mobility disorders and those who live far from tertiary healthcare centers. Furthermore, telemedicine has emerged as a tool that allows the provision of faster and more timely care to patients who are awaiting evaluation by a specialist (9). In January 2015, the HHT created a teleneurology program for its patients based out of the Neurology Department, with the aim of improving access to specialists through an appointment with a general practitioner at a local primary healthcare center with the synchronous telepresence of the neurologist located at HHT.

The present study aimed to characterize the population of patients seen between 2015 and 2019 according to the diagnosed pathology. During this period, a total of 2,904 patients were seen, with a total of 5,874 consultations by telepresence, which represents a national milestone for the volume of patients seen. The teleneurology program has covered, since its inception, a wide spectrum of neurological diagnoses, and the most common diagnoses are described in this study. The most common pathologies reported in this study are headache, Alzheimer's 


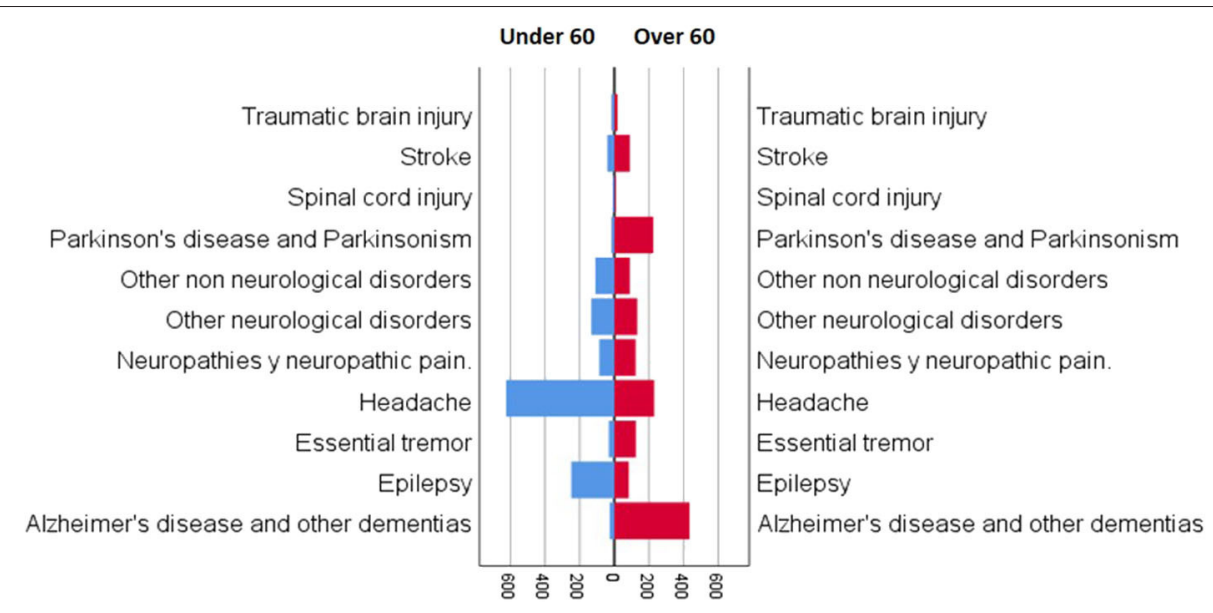

FIGURE 3 | Patients categorized by age (under 60 and over 60) and neurological pathology in the teleneurology program at the Hospital las Higueras of Talcahuano.

TABLE 3 | Patients categorized by age (under 60 and over 60) and neurological pathology in the teleneurology program at the Hospital las Higueras of Talcahuano.

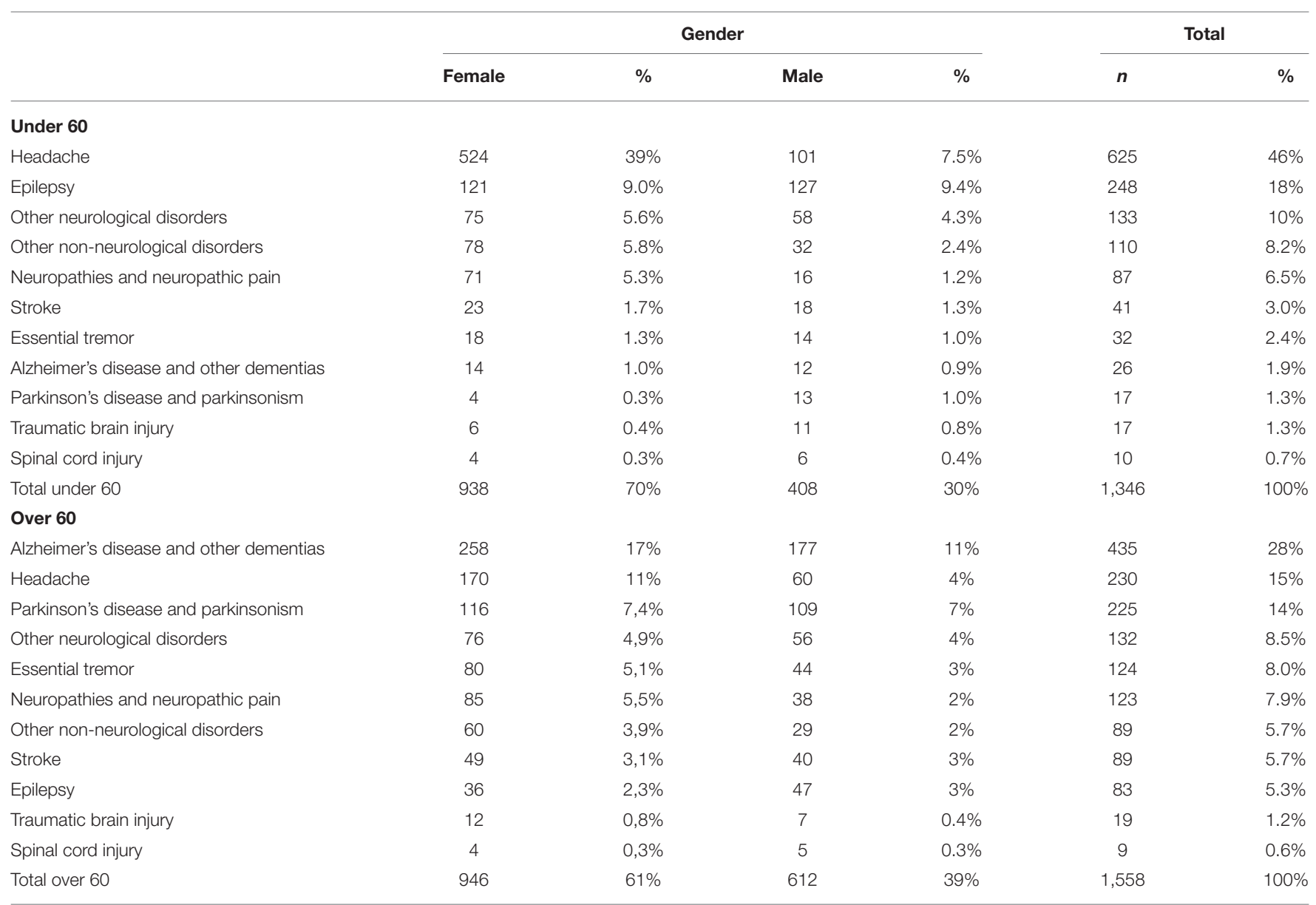

disease and other dementias, and epilepsy. However, these frequencies changed when the patients were categorized by age; as expected, patients over 60 years old showed an increasing prevalence in neurodegenerative diseases and stroke. These patients showed a greater cognitive and mobilization disability; therefore, they are patients who require greater healthcare, which is facilitated by teleneurology. The frequency of cases reported in the teleneurology program is similar to the observed global 
burden of neurological diseases (19). Interestingly, we observed a different number of patients between genders. This is likely to be rooted in cultural differences, regarding patient compliance of Chilean females and males, characteristic in developing countries (24).

This study analyzed the disease burden on outpatients and did not consider patients who receive care in an emergency setting and require hospitalization; hence, the teleneurology program does not report a high number of stroke patients because these patients are treated at the HHT. The stroke patients who were included in this study were medical referrals from the HHT. Usually, these patients benefit from the teleneurology program when they cannot attend the hospital for followup after discharge from HHT. Therefore, in our opinion, the implementation of similar teleneurology programs could be aimed at controlling the burden of ambulatory disease, and a different program might be required for the treatment of stroke in an emergency context, depending on the availability of health system resources, as previously described in Chile (10) and globally (25).

Previous studies have reported the benefits of teleneurology consultations in outpatient settings in first-world countries (20); however, our study for the first time provides relevant information on the pathologies that are possible to treat through a teleneurology network in a developing country. The report of this experience clearly presents an opportunity to achieve greater equity in the medical coverage needed for patients with neurological diseases in a country with an inadequate geographical distribution of neurologists. It is interesting to note that, as of 2018, the telepresence program followed 634 patients treated via the telepresence modality, demonstrating that most patients $(574,86.3 \%)$ benefit from maintaining control of their condition via the same telepresence system. Furthermore, it should be noted that only 37 patients $(5.8 \%)$ were referred to the tertiary level, which agrees with previous reports (20).

The future challenge for our teleneurology team is to dedicate time and effort to increase awareness of the importance of telemedicine among healthcare workers. Additionally, special effort must be exerted to convince the authorities and private parties of the importance of this service to guarantee greater support from policy makers. Currently, we are working on diversifying teleneurology services, which include call centers, teleneurology at home, and an education platform open to the community, and we are also collaborating to create new telemedicine units for additional specialties at HHT.

\section{REFERENCES}

1. Gobierno de Chile. Insituto Nacional de Estadísticas de Chile. (INE) (2020). Available online at: https://www.ine.cl/ (accessed September 30, 2020).

2. Guillou M, Carabantes CJ, Bustos FV. [Availability of physicians and specialists in Chile]. Rev Med Chil. (2011) 139:55970. doi: 10.4067/S0034-98872011000500001

\section{CONCLUSIONS}

The implementation of teleneurology programs such as ours could solve similar problems of lack of access to specialists in different regions of our country and the world. Our work group believes that the teleneurology program adequately responds to most outpatient conditions that increase the burden of neurological disease. Through the teleneurology program, we can easily determine which patients can continue follow-up via telemedicine and which need to be referred to tertiary healthcare facilities.

\section{DATA AVAILABILITY STATEMENT}

The original contributions presented in the study are included in the article/Supplementary Material, further inquiries can be directed to the corresponding author/s.

\section{ETHICS STATEMENT}

The studies involving human participants were reviewed and approved by Ethics Committee of the Talcahuano Health Service. Written informed consent for participation was not required for this study in accordance with the national legislation and the institutional requirements.

\section{AUTHOR CONTRIBUTIONS}

FC contributed to the study conception and design, patients' medical care, and manuscript writing. PA-S contributed to manuscript writing and English editing. LP, MM, and JG contributed to the patients' medical care. GV supervised the teleprocesses for the teleneurology program at HHT. CA contributed to the coordination of researchers, statistical analysis, manuscript writing, and English editing. All authors contributed to the article and approved the submitted version.

\section{ACKNOWLEDGMENTS}

We thank all the staff of the Neurology Unit at the HHT for their invaluable contributions to this work.

\section{SUPPLEMENTARY MATERIAL}

The Supplementary Material for this article can be found online at: https://www.frontiersin.org/articles/10.3389/fneur. 2020.595577/full\#supplementary-material

3. Sistema Estadístico Nacional. Instituto Nacional De Estadísticas. (2019). Available online at: https://www.ine.cl/ (accessed October 6, 2019).

4. Ministerio de Salud de Chile. Informe Sobre Brechas De Personal De Salud Por Servicio De Salud. Santiago, CA (2017).

5. Ministerio de Salud de Chile. Informe Sobre Brechas de Personal de Salud Por Servicio de Salud. Santiago de Chile (2018). Available online at: https://www. minsal.cl/wp-content/uploads/2015/08/Informe-Brechas-RHS-en-SectorP'ublico_Abril2017.pdf (accessed March 7, 2019). 
6. FONASA. Bases de datos, Informes, Estudios y Documentos. (2017). Available online at: https://www.fonasa.cl/sites/fonasa/institucional/archivos\# documentos-estadisticos-institucionales (accessed October 9, 2019).

7. Ministerio de Salud de Chile. $4^{\circ}$ Informe Trimestral de Garantías de Oportunidades Respecto a los Retrasos en Régimen GES y lista de Espera no GES. Gabinete Subsecretaria de Redes Asistenciales. Santiago (2020). Available online at: https://www.minsal.cl/wp-content/uploads/2020/05/Ord251-Glosa-06.pdf (accessed May 20, 2020).

8. Rienzo A, Galindo C. Telemedicine services in the chilean public sector; a first quantitative study. In 2015 CHILEAN Conference on Electrical, Electronics Engineering, Information and Communication Technologies (CHILECON). Santiago: IEEE (2015). p. 215-8.

9. Constanzo F, Aracena-Sherck P, Hidalgo JP, Peña L, Marrugo M, Gonzalez J, et al. Contribution of a synchronic teleneurology program to decrease the patient number waiting for a first consultation and their waiting time in Chile. BMC Med Inform Decis Mak. (2020) 20:20. doi: 10.1186/s12911-020-1034-2

10. Mansilla E, Mazzon E, Cárcamo D, Jurado F, Lara L, Miryaarévalo, et al. Telestroke in Chile: 1 year experience at 7 hospitals. Rev Med Chil. (2019) 147:1109-15. doi: 10.4067/s0034-98872019000901107

11. Constanzo F, Aracena-Sherck P, Hidalgo JP, Muñoz M, Vergara G, Alvarado C. Validation of a patient satisfaction survey of the Teleneurology program in Chile. BMC Res Notes. (2019) 12:359. doi: 10.1186/s13104-019-4358-1

12. Mutgi SA, Zha AM, Behrouz R. Emerging subspecialties in neurology: telestroke and teleneurology. Neurology. (2015) 84:e191-3. doi: 10.1212/WNL.0000000000001634

13. Timpano F, Pirrotta F, Bonanno L, Marino S, Marra A, Bramanti P, et al. Videoconference-based mini mental state examination: a validation study. Telemed J E-Health. (2013) 19:931-7. doi: 10.1089/tmj.2013.0035

14. Klein BC, Busis NA. Author response: COVID-19 is catalyzing the adoption of teleneurology | neurology. Neurology. (2020) 94:903-4. doi: 10.1212/WNL.0000000000009494

15. Camila Meza Sparza. Teleconsultas: la Tecnología a Favor del Paciente en Tiempos de Pandemia - Universidad Católica de la Santísima Concepción. Noticias UCSC (2020). Available online at: https://www.ucsc.cl/noticias/ teleconsultas-la-tecnologia-a-favor-del-paciente-en-tiempos-de-pandemia/ (accessed May 20, 2020).

16. Judd E, Hollander MD, Brendan G, Carr MD. Virtually perfect? telemedicine for covid-19. N Engl J Med. (2020) 382:1679-81. doi: 10.1056/NEJMp2003539

17. Feigin VL, Vos T, Nichols E, Owolabi MO, Carroll WM, Dichgans M, et al. The global burden of neurological disorders: translating evidence into policy. Lancet Neurol. (2020) 19:255-65. doi: 10.1016/S1474-4422(19)30411-9
18. Feigin VL, Vos T. Global burden of neurological disorders: from global burden of disease estimates to actions. Neuroepidemiology. (2019) 52:12. doi: 10.1159/000495197

19. Carroll WM. Global, regional, and national burden of neurological disorders, 1990-2016: a systematic analysis for the global burden of disease study 2016. Lancet Neurol. (2019) 18:418-9. doi: 10.1016/S1474-4422(1 8)30499-X

20. Almallouhi E, Al Kasab S, Harvey JB, Simpson KN, Turner N, Debenham E, et al. Teleneurology network to improve access to neurologists for patients in rural areas: a real-world experience. Telemed J E Health. (2020) 26:1103. doi: $10.1089 /$ tmj. 2018.0290

21. LeRouge CM, Gupta M, Corpart G, Arrieta A, Davis LE, Richardson SP, et al. Telemedicine in neurological disorders: opportunities and challenges. Telemed J E Health. (2019) 25:541-50. doi: 10.1089/tmj.2018.0101

22. Davis LE, Richardson SP, Harnar J, Fraser A, LaChey-Barbee LA, King MK. Using teleneurology to deliver chronic neurologic care to rural veterans: analysis of the first 1,100 patient visits. Telemed J E Health. (2018) 25:2748. doi: 10.1089/tmj.2018.0067

23. Feigin VL, Abajobir AA, Abate KH, Abd-Allah F, Abdulle AM, Abera SF, et al. Global, regional, and national burden of neurological disorders during 19902015: a systematic analysis for the global burden of disease study 2015. Lancet Neurol. (2017) 16:877-97. doi: 10.1016/S1474-4422(17)30299-5

24. Lertmaharit S, Kamol-Ratankul P, Sawert H, Jittimanee S, Wangmanee S. Factors associated with compliance among tuberculosis patients in Thailand. J Med Assoc Thai. (2005) 88(Suppl. 4):S149-56.

25. Ohannessian R, Schott AM, Colin C, Nighoghossian N, Medeiros de Bustos E, Moulin T. Acute telestroke in France: a systematic review. Revue Neurol. (2020) 176:316-24. doi: 10.1016/j.neurol.2019.11.004

Conflict of Interest: The authors declare that the research was conducted in the absence of any commercial or financial relationships that could be construed as a potential conflict of interest.

Copyright (C) 2020 Constanzo, Aracena-Sherck, Peña, Marrugo, Gonzalez, Vergara and Alvarado. This is an open-access article distributed under the terms of the Creative Commons Attribution License (CC BY). The use, distribution or reproduction in other forums is permitted, provided the original author(s) and the copyright owner(s) are credited and that the original publication in this journal is cited, in accordance with accepted academic practice. No use, distribution or reproduction is permitted which does not comply with these terms. 